\title{
Editorial / Editorial
}

Grave confrontations and intense changes coincide with the most prolific moments in the development of thought, bringing with them epistemological challenges. The most challenging questions of today's global politics show us that we live in one such moment, and in this edition, we bring together articles that seek to offer elements for an analysis of the Brazilian, Latin American and international conjunctures including long-term structural processes as well as those that seem occasional and immediate.

Reflections on nationalism and internationalism, seen as complementary phenomena, are central to the Nationalities Observatory's preoccupations. We believe that one of the shortcomings of those that seek to explain the nation simply with ideas rooted in such objective factors as territory, language, population, natural resources, economic life, culture, etc. is the lack of attention given to global processes that spawned the political entity known as the nation-state. The ambiguities and inherent contradictions of this form of organisation come from the dynamics of the widely accepted system of production of material and non-material goods: capitalism.

In this perspective, we present a promising study that discusses Antonio Gramsci's internationalist thinking and also highlights his attachment to his homeland and his struggle for the unification of Italy within a popular base. Using biographical data and the political writings of the well-known communist militant, Daniel Gomes offers his theoretical interpretation on the interface between nationalism and internationalism. This debate continues to be extremely relevant, as shown by Robert Austin in his article on the future of socialism in the 21 st century using as reference the collection Latin America's Turbulent Transitions (2013). The United States' hegemony in Latin America and Caribbean, as well as the surge of progressive governments in the region, are the objects 
of careful critical examination. For the author, the national and international bourgeoisies have adopted new tactics for confronting populist regimes and social movements. Constitutional coups are more frequent such as those that took place in Honduras, Paraguay and Brazil not to mention the attempts still underway in Venezuela.

Despite being scarcely recognized in the Brazilian academic world, two intellectuals are remembered in this issue for their original contributions to the understanding of the historic formative processes of Latin American nations: Manoel Bomfim (1868-1932) and Ruy Mauro Marini (1932-1997). With reference to Marini's theoretical renewal of the concept of sub-imperialism, Argentinian researcher Claudio Katz discusses its relevance to clarifying the contemporary reality of regions with prolonged states of war, such as the Arabic world. On the other hand, young researchers Gislânia Freitas and Larissy Leal apply themselves to the notion of "social parasitism", seeking to provide evidence of its analytical richness compared with the racism dominating European scientific circles and influential in Brazil at the beginning of the 20th century. Even in 1905 Bomfim published Latin America: evils of origin [América Latina: males de origem], in which he critiqued the predatory nature of the Iberian colonial enterprise and contested the mistaken generalisations made of the peoples of the New World.

The following articles are dedicated to human migrations, a recurring theme in World Tensions ever since its first issue published Benedict Anderson's lecture entitled "The Issues of Contemporary Nationalisms". International migratory flows are painful phenomena that everyday increase in intensity and attract the attention of international relations scholars. In 2015, thousands of people fled their countries and sought shelter in Europe, generating contradictory activities on the part of civil society, national states and the European Union. From the theoretical-epistemological formulations of the so-called English School, Fabiana Sander and Thais de Souza seek to understand what these initiatives represent for global society and, in particular, for the European one. The way in which the topic of human migrations hasbeen handled by multilateral organisations, especially the United Nations, is the object of 
Marcela Tarter da Rosa's interest. Her focus is directed at assessing how international organisations respond or do not respond effectively to migrant rights.

On the domestic scene, the political dilemmas that Brazilians have to face include both the rapid diffusion of ideologies and sentiments through social media and those of electoral politics. A good example are street manifestations, which spread rapidly throughout the country, reaching their peak in June 2013, with students' protest against the increase in price of public transportation. Angelo Girotto examines the organisation and dynamics of social movements in the age of the internet, having as his main interlocutor Castells, whose conceptualization is contrasted with the ideas of other social scientists.

In a more regional context, Peru, our neighbour located in the western part of South America, would like to project itself toward the Atlantic Ocean, crossing many countries' roadways and stimulating the creation of a regional infrastructure by allying economic objectives with national defence policies. The geopolitical and strategic motivations for such a big undertaking make up the core of Rodrigo Pereira Pinto's article.

Finally, this edition comes to a close. We wish you all an enjoyable reading!

The Editors 